\title{
Phylogeny and cryptic diversification in Southeast Asian flying geckos
}

\author{
Rafe M. Brown ${ }^{\mathrm{a}, \mathrm{b}, *}$, Cameron D. Siler ${ }^{\mathrm{a}, \mathrm{b}}$, L. Lee Grismer ${ }^{c}$, Indraneil Das ${ }^{\mathrm{d}}$, Jimmy A. McGuire ${ }^{\mathrm{e}, \mathrm{f}}$ \\ ${ }^{a}$ Biodiversity Institute, University of Kansas, Lawrence, KS 66045-7561, USA \\ ${ }^{\mathrm{b}}$ Department of Ecology and Evolutionary Biology, University of Kansas, Lawrence, KS 66045-7561, USA \\ ${ }^{\mathrm{c}}$ Department of Biology, La Sierra University, Riverside, CA 92515, USA \\ ${ }^{\mathrm{d}}$ Institute of Biodiversity and Environmental Conservation, Universiti Malaysia Sarawak, 94300 Kota Samarahan, Sarawak, Malaysia \\ e Museum of Vertebrate Zoology, University of California, Berkeley, CA 94720-3160, USA \\ ${ }^{\mathrm{f}}$ Department of Integrative Biology, University of California, Berkeley, CA 94720-3160, USA
}

\section{A R T I C L E I N F O}

\section{Article history:}

Received 8 March 2012

Revised 31 May 2012

Accepted 13 June 2012

Available online 26 June 2012

\section{Keywords:}

Canopy specialists

Flying geckos

Parachute geckos

Southeast Asia

Vertebrate gliders

\begin{abstract}
A B S T R A C T
The closed-canopy forests of Southeast Asia are home to an impressive number of vertebrates that have independently evolved morphologies that enhance directed aerial descent (gliding, parachuting). These assemblages include numerous mammal, frog, snake, and lizard clades. Several genera of gekkonid lizards, in particular, have evolved specialized structures such as cutaneous expansions, flaps, and midbody patagia, that enhance lift generation in the context of unique gliding and parachuting locomotion. The genus Ptychozoon represents arguably the most morphologically extreme, highly specialized clade of gliding geckos. Despite their notoriety and celebrated locomotor ability, members of the genus Ptychozoon have never been the subject of a species-level molecular phylogenetic analysis. In this paper, we utilize molecular sequence data from mitochondrial and nuclear gene fragments to estimate the evolutionary relationships of this unique group of flying geckos. Capitalizing on the recent availability of genetic samples for even the rarest of known species, we include the majority of known taxa and use model-based phylogenetic methods to reconstruct their evolutionary history. Because one species, $P$. kuhli, exhibits an unusually wide distribution coupled with an impressive range of morphological variation, we additionally use intensive phylogeographic/population genetic sampling, phylogenetic network analyses, and Bayesian species delimitation procedures to evaluate this taxon for the possible presence of cryptic evolutionary lineages. Our results suggest that $P$. kuhli may consist of between five and nine unrecognized, distinct species. Although we do not elevate these lineages to species status here, our findings suggest that lineage diversity in Ptychozoon is likely dramatically underestimated.
\end{abstract}

(c) 2012 Elsevier Inc. All rights reserved.

\section{Introduction}

Among Southeast Asia's myriad of highly specialized gliding vertebrates (Colbert, 1967; Russell, 1979a; Emerson and Koehl, 1990; Goldingay and Scheibe, 2000; Dudley et al., 2007), flying geckos of the genus Ptychozoon have inspired more awe ${ }^{1}$ and speculation than perhaps any other group of Asian geckos (Annandale, 1904, 1905; Barbour, 1912; de Rooij, 1915; Tweedie, 1954; Tiwari, 1961; Pong, 1974; Tho, 1974; Taylor, 1975; Russell, 1979a,b). Most species in this small genus (seven species) are rarely encountered

* Corresponding author at: Biodiversity Institute, 1345 Jayhawk Blvd., Lawrence, KS 66045, USA. Fax: +1 7858645335.

E-mail addresses: rafe@ku.edu (R.M. Brown), camsiler@ku.edu (C.D. Siler) lgrismer@lasierra.edu (L. Lee Grismer), idas@ibec.unimas.my (I. Das), mcguirej@ berkeley.edu (J.A. McGuire).

1 "Tiny wing like flaps were on either side of the face, other broad winglike expansions were along the side of its body, a similar flap bordered the back of the thigh. The long tail had a series of frills on each side, as if scalloped lace had been sewn on the sides for decoration" (Taylor, 1975, p. 47). by biologists and, as a consequence, are poorly represented in natural history collections (Brown et al., 1997). The majority of species are known from the Southeast Asian mainland and adjacent Sundaland island archipelagos (Taylor, 1915, 1922a,b; Brown et al., 1997; Das and Vijayakumar, 2009), but three taxa, P. kuhli, P. lionotum, and $P$. trinotaterra, possess geographic ranges extending northward well into Indochina (Taylor, 1963; Inger and Colwell, 1977; Biswas and Sanyal, 1980; Das, 1994a,b; Brown, 1999; Pauwels et al., 2000; Stuart and Emmett, 2006; Grismer et al., 2008; Grismer, 2011), and a single species ( $P$. lionotum) has been recorded from the Indian subcontinent (Pawar and Biswas, 2001; Venugopal, 2010).

Until recent taxonomic work clarified species boundaries (Brown et al., 1997; Brown, 1999; Das and Vijayakumar, 2009), specimen identification in museum collections was often tenuous (RMB, pers. obs), with numerous conflicting literature accounts resulting in general confusion regarding species identifications and geographic distributions (Cantor, 1847; Günther, 1864, 1885; Boulenger, 1885; Flower, 1896; Stejneger, 1907; Smith, 1930, 1935; Taylor, 1928, 1963; Wermuth, 1965; Dring, 1979; Bobrov, 